\title{
A Procedure for Selecting and Isolating Specific Auxotrophic Mutants of Mycobacterium smegmatis
}

\author{
By K. T. HOLLAND* AND C. RATLEDGE \\ Department of Biochemistry, University of Hull, Hull, $H U 6{ }_{7} R X$
}

(Accepted for publication I8 March I97I)

SUMMARY

Mycobacterium smegmatis is mutated by exposure to nitrosoguanidine at $\mathrm{O} \cdot \mathrm{I}$ and $1.0 \mathrm{mg} . / \mathrm{ml}$. for 15 and $60 \mathrm{~min}$. After incubation for $24 \mathrm{~h}$. in a complete medium, to allow for phenotypic expression, isoniazid (at $0 . \mathrm{I} \mathrm{mg} . / \mathrm{ml}$. for $24 \mathrm{~h}$.) is used to reduce the numbers of unwanted mutants and surviving wild-type bacteria in a procedure analagous to penicillin selection with other bacteria.

\section{INTRODUCTION}

When mutants of Mycobacterium phlei, produced by a variety of treatments, were isolated without an enrichment procedure they required mainly glycine and serine for growth (Konichova-Radochova \& Malek, 1969; Konichova-Radochova, Konicek \& Malek, 1970). No technique, however, has previously been described for selecting and isolating specific auxotrophs of mycobacteria. Such a technique has now been evolved and is presented here. A preliminary account has already been published (Holland \& Ratledge, 1970).

\section{METHODS}

Organism and growth. Mycobacterium smegmatis was grown on a minimal medium previously described (Ratledge \& Hall, 1970), without removing trace metals. The medium, when required, was solidified with high purity agar (Oxoid no. I, Oxoid Laboratories) at $\mathrm{I} \cdot 5 \%(\mathrm{w} / \mathrm{v})$. Nutrient broth and nutrient agar (Difco Laboratories) were also used. Supplements were added to sterile media from sterile stock solutions. Tween 80 was autoclaved as a $10 \%(\mathrm{v} / \mathrm{v})$ solution in water.

Bacteria in liquid media were always continuously shaken at $250 \mathrm{rev} . / \mathrm{min}$. All cultures were incubated at $37^{\circ}$. For determining viable bacterial count, serial dilutions were made in $0.85 \%(\mathrm{w} / \mathrm{v}) \mathrm{NaCl}+\mathrm{I} \%(\mathrm{v} / \mathrm{v})$ Tween 80 and samples $(0.2 \mathrm{ml}$.) dispersed on solid medium with a glass spreader. The turbidity of cultures at $660 \mathrm{~nm}$. was used whenever a quick indication of the viable count was necessary.

Mutagenesis and phenotypic expression of mutants. $N$-Methyl- $N^{\prime}$-nitro- $N$-nitrosoguanidine (nitrosoguanidine) was used according to Adelberg, Mandel \& Chen (I965). For optimum results, bacteria were harvested by centrifuging near the end of log-phase growth, washed with water and resuspended in minimal medium at $\mathrm{pH} 6 \cdot 3+\mathrm{I} \%(\mathrm{v} / \mathrm{v})$ Tween 80 to a concentration of about $10^{8}$ bacteria/ml., with nitrosoguanidine usually at 100 or $1000 \mu \mathrm{g} . / \mathrm{ml}$. being added beforehand. After incubation, samples ( $10 \mathrm{ml}$.) were membrane-filtered and the bacteria washed with $0 \cdot 2 \mathrm{M} \mathrm{KH}_{2} \mathrm{PO}_{4}+\mathrm{KOH}$ buffer, $\mathrm{pH} \mathrm{6.3.} \mathrm{The} \mathrm{membrane} \mathrm{was} \mathrm{transferred}$ into $100 \mathrm{ml}$. nutrient broth $+\mathrm{I} \%(\mathrm{v} / \mathrm{v})$ Tween 80 in a $250 \mathrm{ml}$. conical flask along with 10 to

\footnotetext{
* Present address: Department of Bacteriology, University of Leeds, Leeds, LS2 9NL.
} 
20 glass balls $\left(0.5 \mathrm{~cm}\right.$. diam.) to dislodge bacteria from the filter and then shaken at $37^{\circ}$ for $24 \mathrm{~h}$.

Selection of mutants. Penicillin cannot be used for enrichment of mutants of mycobacteria as they are insensitive to it (Konicek \& Malek, I968). Isonicotinic acid hydrazide (isoniazid) is, however, highly active against mycobacteria killing only actively growing bacteria (Winder, 1964). A ro ml. sample of bacteria, following nitrosoguanidine treatment and a period for phenotypic expression, was membrane-filtered, washed well with buffer and transferred into roo $\mathrm{ml}$. of minimal medium with I \% (v/v) Tween 80 , Ioo $\mu \mathrm{g}$. isoniazid $/ \mathrm{ml}$. and every chemically defined growth factor listed below except the one for which auxotrophic mutants were required. Glass balls were again added to dislodge bacteria from the membrane. The medium was incubated for $24 \mathrm{~h}$. Bacteria (usually a $10 \mathrm{ml}$. sample) were collected and washed as before, then resuspended in the usual manner in $100 \mathrm{ml}$. of minimal medium with I $\%(v / v)$ Tween 80 and the growth factor for the required auxotroph. The medium was shaken for $24 \mathrm{~h}$. Samples ( $\mathrm{m} \mathrm{ml}$.) were serially diluted (see above), plated out on solidified minimal medium containing I \% (v/v) Tween 80 and the growth factor for the required auxotroph. After incubation for 3 days mucoid colonies developed and replica plating of those plates with 50 to 150 colonies was carried out following the procedure of Lederberg \& Lederberg (I952).

Growth factors. The following growth factors (final concentrations in $\mu \mathrm{g} . / \mathrm{ml}$.) were included in enrichment medium containing isoniazid: L-alanine (10), L-arginine (IO), DLaspartic acid (IO), L-cystine (IO), L-glutamate (IO), glycine (IO), L-histidine (IO), L-hydroxyproline (IO), L-isoleucine (IO), L-leucine (I0), L-lysine (I0), L-methionine (IO), L-phenylalanine (IO), L-proline (IO), L-serine (IO), L-threonine (IO), L-tryptophan (IO), L-tyrosine (I0), L-valine (IO), shikimic acid (I5), salicylic acid (IO), riboflavin (I), thiamine. $\mathrm{HCl}$ (I), biotin (I), nicotinamide (2), 4-aminobenzoate (2), pantothenic acid (I), pyridoxamine. $\mathrm{HCl}(0 \cdot 8)$, folic acid (0.2), inositol (2), adenine (20), guanine (20), uracil (20), xanthine (20), thymidine (20), cytosine (20).

\section{RESULTS AND DISCUSSION}

Successful auxotroph selection depends upon bacteria being maintained in a dispersed form. Clumps of Mycobacterium smegmatis were disaggregated when I \% (v/v) but not $0.05 \%$ Tween 80 was incorporated in media, but constant shaking was also needed to maintain dispersion. Under these conditions sustained logarithmic growth, with a mean generation time of $3 \mathrm{~h}$., occurred in both minimal medium and nutrient broth.

Optimum concentration of mutagen and most suitable medium for exposure to mutagen. The decrease in viability of Mycobacterium smegmatis when treated with nitrosoguanidine at either 100 or $1000 \mu \mathrm{g} . / \mathrm{ml}$. in minimal medium or at $60 \mu \mathrm{g} . / \mathrm{ml}$. in nutrient broth was followed (see Table I). The lethal effect of nitrosoguanidine on bacteria suspended in broth was, however, considered too great and all subsequent experiments were carried out using minimal medium with nitrosoguanidine at two concentrations (I00 and $1000 \mu \mathrm{g} . / \mathrm{ml}$.).

Determination of optimum time for exposure to mutagen. Using the above conditions the maximum number of auxotrophic mutants were produced after $45 \mathrm{~min}$. contact with nitrosoguanidine at both 100 and $1000 \mu \mathrm{g}$. $/ \mathrm{ml}$. (Table I). However, we recommend that bacteria be exposed for two periods - $15 \mathrm{~min}$. and about $60 \mathrm{~min}$. - for each of the two concentrations of mutagen.

Determination of the optimum time for phenotypic expression. The optimum time to leave the mutated bacteria in complete medium for phenotypic expression was $24 \mathrm{~h}$. This applied to all bacteria no matter how long they had been in contact with nitrosoguanidine. 
Without this step, the number of mutants isolated was about $50 \%$ less; if bacteria were incubated for longer than $24 \mathrm{~h}$. the number of isolates again decreased.

Non-selective isolation of mutants. Without isoniazid to select specific auxotrophs, mutants could be isolated by plating out samples from the medium used for phenotypic expression on to nutrient agar $+\mathrm{I} \%(\mathrm{v} / \mathrm{v})$ Tween 80 . Colonies were subsequently replica-plated on minimal medium containing either all amino acids, purines + pyrimidines or vitimins. Combinations

\title{
Table I. Survival of Mycobacterium smegmatis and production of mutants after exposure to nitrosoguanidine
}

\begin{abstract}
Bacteria were suspended in either nutrient broth $+1 \%(\mathrm{v} / \mathrm{v})$ Tween 80 medium or in a minimal medium $+1 \%(\mathrm{v} / \mathrm{v})$ Tween 80 to a density of $10^{8}$ bacteria $/ \mathrm{ml}$. Nitrosoguanidine was then added. Cultures were shaken at $250 \mathrm{rev} . / \mathrm{min}$. at $37^{\circ}$. For total viable count of surviving bacteria, samples ( $\mathrm{I} \mathrm{ml}$.) were immediately diluted in Tween $80+$ saline (see Methods) and plated out on nutrient agar. For count of mutants, samples ( $10 \mathrm{ml}$.) were processed as given in Methods and, after incubation in nutrient broth for $24 \mathrm{~h}$., mutants were isolated without the isoniazid selection procedure.
\end{abstract}

\begin{tabular}{|c|c|c|c|c|c|}
\hline \multirow[b]{3}{*}{$\begin{array}{l}\text { Time of } \\
\text { treatment } \\
\text { (min.) }\end{array}$} & \multicolumn{5}{|c|}{ Nitrosoguanidine at } \\
\hline & \multirow[b]{2}{*}{$\begin{array}{c}60 \mu \mathrm{g} . / \mathrm{ml} \text {. } \\
\text { (in nutrient } \\
\text { broth) } \\
\text { Survivors } \\
(\%)\end{array}$} & \multicolumn{2}{|c|}{$\begin{array}{c}\mathrm{IO0} \mu \mathrm{g} \cdot / \mathrm{ml} \text {. } \\
\text { (in minimal medium) }\end{array}$} & \multicolumn{2}{|c|}{$\begin{array}{c}\mathrm{I} 000 \mu \mathrm{g} . / \mathrm{ml} \text {. } \\
\text { (in minimal medium) }\end{array}$} \\
\hline & & $\begin{array}{l}\text { Survivors } \\
(\%)\end{array}$ & $\begin{array}{c}\text { Mutants } \\
\text { in surviving } \\
\text { population } \\
(\%)\end{array}$ & $\begin{array}{l}\text { Survivors } \\
(\%)\end{array}$ & $\begin{array}{c}\text { Mutants } \\
\text { in surviving } \\
\text { population } \\
(\%)\end{array}$ \\
\hline 10 & 20 & - & - & - & - \\
\hline I5 & - & 26 & $\mathbf{I} \cdot 3$ & 16 & $2 \cdot 3$ \\
\hline 20 & I & - & - & - & - \\
\hline 30 & 0 & 14 & $1 \cdot 7$ & 7 & $4 \cdot 3$ \\
\hline 45 & - & 12 & $2 \cdot 8$ & 3 & IO \\
\hline 60 & - & 9 & $2 \cdot 4$ & I & $8 \cdot 2$ \\
\hline
\end{tabular}

Table 2. Effect of isoniazid on the recovery of the wild-type and an amino acid auxotroph from a mixed culture in minimal medium

Both wild-type and mutant were grown separately on nutrient broth $+\mathrm{I} \%(\mathrm{v} / \mathrm{v})$ Tween 80 , membrane filtered, washed and then mixed in minimal medium containing $\mathrm{I} \%(\mathrm{v} / \mathrm{v})$ Tween 80 and isoniazid. The mixed culture was shaken at $37^{\circ}$ for $30 \mathrm{~h}$.

$\begin{array}{lll}\text { Initially in mixed culture... } & \begin{array}{c}\text { Auxotroph* } \\ 3.5 \times 10^{6}\end{array} & \begin{array}{c}\text { Wild-type } \\ 2.35 \times 10^{6}\end{array} \\ \text { After exposure to isoniazid at: } & 7.9 \times 10^{5} & 2.3 \times 10^{8} \\ 0 \mu \mathrm{g} . / \mathrm{ml} . & 5.4 \times 10^{6} & 3.8 \times 10^{6} \\ 10 \mu \mathrm{g} . / \mathrm{ml} . & 3.0 \times 10^{6} & 1 \cdot 0 \times 10^{4} \\ 100 \mu \mathrm{g} . / \mathrm{ml} . & 3.5 \times 10^{6} & 3.9 \times 10^{3}\end{array}$

* The exact nutritional requirement was not defined beyond the need for an amino acid.

of these growth factors were also used. Although the exact nutritional requirement of each mutant was not defined further, only a few mutants showed a requirement for more than one group of growth factors. In a typical experiment $55 \%$ of the mutants required an amino acid, $19 \%$ a purine or pyrimidine and $16 \%$ a vitamin. Auxotrophic mutants requiring asparagine were obtained by substituting $\left(\mathrm{NH}_{4}\right)_{2} \mathrm{SO}_{4}$ at $0.5 \mathrm{~g}$./1. for L-asparagine in the minimal medium and mutants resistant to streptomycin, isoniazid and $p$-aminosalicylate 
could also be obtained. Mutants with an altered chromogenesis and also a few temperaturesensitive mutants were noted.

Isolation of specific auxotrophs. Isoniazid at various concentrations, up to $1000 \mu \mathrm{g} . / \mathrm{ml}$., did not produce any significant decrease in the viable count of an auxotroph, obtained by the non-selective method, whereas at 100 or $1000 \mu \mathrm{g} . / \mathrm{ml}$. it produced a substantial killing of the wild-type (Table 2). The resistance of the auxotroph to isoniazid can be attributed to the inability of the drug to be bactericidal to non-growing bacteria (Winder, I964). Thus isoniazid can be used to enrich a mixed culture in favour of any auxotroph which may be present and its use with mycobacteria parallels that of penicillin with other bacteria.

The efficacy of this method in isolating specific mutants has been demonstrated by the facility with which auxotrophs of Mycobacterium smegmatis requiring salicylic acid, tyrosine, tryptophan and phenylalanine, as well as some demonstrating a requirement for shikimic acid, have been obtained. The number of colonies showing inability to grow on minimal medium but being able to grow on the same medium plus the specific growth factor was usually between $0.2 \%$ and $0.9 \%$ of the final colony population.

Isolated auxotrophs have shown a high degree of stability without any change in nutritional requirements over a period of 12 months. There is no reason why this technique could not be applied with equal success to other species of mycobacteria.

We thank Mr M. J. Hall for his help with part of this work. The Wellcome Trust is gratefully thanked for a grant supporting one of us (K.T.H.) and for their grants for chemicals and equipment.

\section{REFERENCES}

Adelberg, E. A., Mandel, M. \& Chen, G. C. C. (1965). Optimal conditions for mutagenesis by $N$-methyl$N^{\prime}$-nitro- $N$-nitrosoguanidine in Escherichia coli K I2. Biochemical and Biophysical Research Communications $18,788-795$.

Holland, K. T. \& RATledge, C. (1970). Auxotrophic mutants of Mycobacterium smegmatis. Journal of General Microbiology 6r, iii-iv.

KoniceK, J. \& MALEK, I. (1968). The application of the penicillin technique for the isolation of auxotrophic mutants in Mycobacterium phlei strain PN. Folia microbiologica 13, $158-160$.

Konichova-RADOchova, M. \& MaLeK, I. (I969). The mutagenic effect of nitrosoguanidine on Mycobacterium phlei PA. Folia microbiologica 14, $20 \mathrm{I}-207$.

Konichova-Radochova, M., KoniceK, J. \& MALEK, I. (1970). The study of mutagenesis in Mycobacterium phlei. Folia microbiologica 15, 88-102.

LEDERBERG, J. \& LEDERBERG, E. M. (1952). Replica plating and indirect selection of bacterial mutants. Journal of Bacteriology 63, 399-406.

RATLEDGE, C. \& HALL, M. J. (I970). Uptake of salicyclic acid into mycobactin S by growing cells of Mycobacterium smegmatis. FEBS Letters 10, 309-312.

WINDER, F. (1964). The antibacterial action of streptomycin, isoniazid and PAS. In Chemotherapy of Tuberculosis, pp. II I-I49. Edited by V. C. Barry. London: Butterworths. 